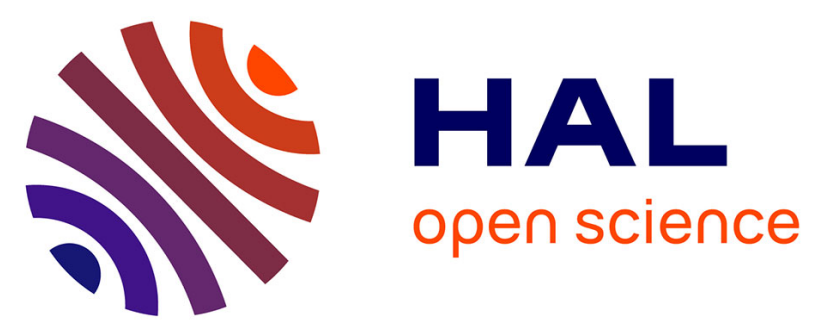

\title{
Xenodens calminechari gen. et sp. nov., a bizarre mosasaurid (Mosasauridae, Squamata) with shark-like cutting teeth from the upper Maastrichtian of Morocco, North Africa
}

Nicholas R Longrich, Nathalie Bardet, Anne S Schulp, Nour-Eddine Jalil

\section{To cite this version:}

Nicholas R Longrich, Nathalie Bardet, Anne S Schulp, Nour-Eddine Jalil. Xenodens calminechari gen. et sp. nov., a bizarre mosasaurid (Mosasauridae, Squamata) with shark-like cutting teeth from the upper Maastrichtian of Morocco, North Africa. Cretaceous Research, 2021, 123, pp.104764. 10.1016/j.cretres.2021.104764 . hal-03407373

\section{HAL Id: hal-03407373 \\ https://hal.science/hal-03407373}

Submitted on 28 Oct 2021

HAL is a multi-disciplinary open access archive for the deposit and dissemination of scientific research documents, whether they are published or not. The documents may come from teaching and research institutions in France or abroad, or from public or private research centers.
L'archive ouverte pluridisciplinaire HAL, est destinée au dépôt et à la diffusion de documents scientifiques de niveau recherche, publiés ou non, émanant des établissements d'enseignement et de recherche français ou étrangers, des laboratoires publics ou privés. 


\section{Journal Pre-proof}

Xenodens calminechari gen. et sp. nov., a bizarre mosasaurid (Mosasauridae, Squamata) with shark-like cutting teeth from the upper Maastrichtian of Morocco, North Africa

Nicholas R. Longrich, Nathalie Bardet, Anne S. Schulp, Nour-Eddine Jalil

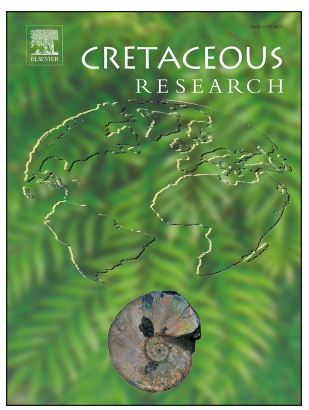

PII: S0195-6671(21)00011-2

DOI: https://doi.org/10.1016/j.cretres.2021.104764

Reference: $\quad$ YCRES 104764

To appear in: Cretaceous Research

Received Date: 22 June 2020

Revised Date: 13 November 2020

Accepted Date: 10 January 2021

Please cite this article as: Longrich, N.R., Bardet, N., Schulp, A.S., Jalil, N.-E., Xenodens calminechari gen. et sp. nov., a bizarre mosasaurid (Mosasauridae, Squamata) with shark-like cutting teeth from the upper Maastrichtian of Morocco, North Africa, Cretaceous Research, https://doi.org/10.1016/ j.cretres.2021.104764.

This is a PDF file of an article that has undergone enhancements after acceptance, such as the addition of a cover page and metadata, and formatting for readability, but it is not yet the definitive version of record. This version will undergo additional copyediting, typesetting and review before it is published in its final form, but we are providing this version to give early visibility of the article. Please note that, during the production process, errors may be discovered which could affect the content, and all legal disclaimers that apply to the journal pertain.

(C) 2021 Published by Elsevier Ltd. 


\section{Author statement}

NRL: Conceptualization, Investigation, Writing, Visualization, Supervision NB: Investigation, Writing Original Draft \& Editing AS: Investigation, Writing Original Draft \& Editing NEJ: Investigation, Writing Original Draft \& Editing 
1 Xenodens calminechari gen. et sp. nov., a bizarre mosasaurid

2 (Mosasauridae, Squamata) with shark-like cutting teeth from the

3 upper Maastrichtian of Morocco, North Africa

4

$5 \quad$ Nicholas R. Longrich ${ }^{\mathrm{a}, *}$, Nathalie Bardet ${ }^{\mathrm{b}}$, Anne S. Schulp ${ }^{\mathrm{c}, \mathrm{d}}$, Nour-Eddine Jalil ${ }^{\mathrm{b}, \mathrm{e}}$

6

$7 \quad{ }^{a}$ Department of Biology and Biochemistry, University of Bath, BA2 7AY, Bath, United 8

$9{ }^{\mathrm{b}}$ CR2P - Centre de Recherche en Paléontologie - Paris, UMR 7207 CNRS-MNHN-Sorbonne 10 Université, Muséum National d'Histoire Naturelle, CP 38, 57 rue Cuvier, 75005 Paris 11 France

$12{ }^{\mathrm{c}}$ Naturalis Biodiversity Center, Darwinweg 2, 2333CR Leiden, the Netherlands

$13{ }^{\mathrm{d}}$ Utrecht University, Faculty of Geosciences, Princetonlaan 8A, 3584CB Utrecht, the 14 Netherlands

${ }^{\text {e }}$ Muséum d'Histoire naturelle de Marrakech, Université Cadi Ayyad, Marrakech Morocco 
18 The mosasaurids (Mosasauridae) were a group of lizards that became highly specialized for 19 marine life in the mid-Cretaceous. By the end of the Cretaceous, they had undergone an 20 adaptive radiation, and showed a wide range of body sizes, locomotor styles, and diets. Their 21 ranks included piscivores, apex predators, and durophages. Here, we report a new taxon, 22 Xenodens calminechari gen. et sp. nov., from the upper Maastrichtian phosphates of 23 Morocco, with dental specializations unlike those of any known reptile. Teeth form a unique 24 dental battery in which short, laterally compressed and hooked teeth formed a saw-like blade. 25 Unique features of tooth structure and implantation suggest affinities with the durophagous 26 Carinodens. The tooth arrangement seen in Xenodens not only expands known disparity of 27 mosasaurids, but is unique among Squamata, or even Tetrapoda. The specialized dentition implies a previously unknown feeding strategy, likely involving a cutting motion used to carve pieces out of large prey, or in scavenging. This novel dental specialization adds to the already considerable disparity and functional diversity of the late Maastrichtian mosasaurids and marine reptiles. This provides further evidence for a diverse marine fauna just prior to the 32 K-Pg extinction.

34 Keywords: Mosasauridae, Squamata, Cretaceous, Maastrichtian, Africa 


\section{Introduction}

Mosasaurids were a highly specialized group of marine reptiles that first appeared in the early

Late Cretaceous, then radiated and dispersed during the latest Cretaceous to occupy a wide

41 range of ecological niches (Russell, 1967; Polcyn et al., 2013; Bardet et al., 2014).

42 Mosasaurids ranged in size from a few meters in length to over 15 meters long (Polcyn et al., 2013); in mass they would have spanned over two orders of magnitude. They were characterized by flipper-like limbs and a shark-like tail (Lindgren et al., 2011; Lindgren et al., 2013) that let them exploit open ocean habitats. Mosasaurids were also specialized divers.

Some species show avascular necrosis ("the bends") suggesting they were capable of deep diving (Rothschild and Martin, 1987), perhaps to kilometers below the surface, as in modern deep-diving elephant seals and sperm whales (Watwood et al., 2006).

In their diets and feeding strategies, mosasaurids were similarly diverse. They evolved a range of dental morphotypes (Massare, 1987; Schulp et al., 2013; Bardet et al., 2015): many had numerous small, conical teeth suitable for spearing and holding small prey items such as fish and cephalopods; others had robust, crushing teeth to crack open shelled prey such as mollusks and turtles; still others had bladelike teeth, suitable for cutting apart large prey items, or massive, conical teeth suitable for tearing apart large vertebrates. Stable isotopes confirm that these diverse tooth structures reflect diverse diets (Polcyn et al., 2013; Schulp et al., 2013). Tooth wear similarly implies diverse feeding strategies (Holwerda et al., 2013). Chalks, in Kansas (Everhart, 2001). These have been extensively studied for over 100 years. However, peak mosasaurid diversity was seen in the Maastrichtian, when mosasaurids showed maximum disparity in terms of size (Polcyn et al., 2013) and tooth morphology

61 (Schulp et al., 2013; Bardet et al., 2015). 

2019; Strong et al., 2020). Here, a diverse assemblage has been described based on teeth and skeletal remains from phosphatic deposits. These are located in the Oulad Abdoun Basin, near Khouribga, and the Ganntour Basin, near Ben Guerir (Cappetta et al., 2014; Bardet et al., 2017). This assemblage has produced taxa and tooth morphologies showing diverse feeding strategies (Bardet et al., 2015). Despite extensive study, new species continue to emerge from these deposits, meaning that diversity is still undersampled.

Recently, a strange new mosasaurid fossil was recovered from the Sidi Chennane phosphate mine, in the Oulad Abdoun Basin (Fig 1), from beds of late Maastrichtian age (Fig.2). The new mosasaurid exhibits a dental battery with numerous small, short, bladelike teeth packed together to form a saw-like cutting edge. Features of the jaws and teeth suggest affinities with the mosasaurid Carinodens, a taxon with crushing teeth (Bardet et al., 2008; Schulp et al., 2009; Holwerda et al., 2013; Mulder et al., 2013; Milàn et al., 2018).

\section{Geological Setting}

81

The new mosasaurid remains come from the Sidi Chennane phosphate mine in the Oulad Abdoun Basin of Khouribga Province, Morocco (Fig. 1). Strata exposed here by mining span the Cretaceous-Paleocene boundary, extending in time from the mid?-late Maastrichtian (Kocsis et al., 2014) into the early and middle Eocene (Fig. 2). The phosphatic deposits are divided into a series of beds or 'couches' for the purposes of mining. 

boundary between Couche I and II corresponds to the Paleocene-Eocene boundary and

to the Cretaceous-Paleogene transition, but the K-Pg boundary itself and the Lower

Paleocene are not preserved (Bardet et al., 2017). Couche III lacks either calcareous fossils, such as ammonites, bivalves, and foraminifera, or organic microfossils, to constrain its age.

However, shark teeth correlate Couche III to the late Maastrichtian (Arambourg, 1935;

Cappetta, 1987). Oxygen and carbon isotope stratigraphy corroborate this assignment (Kocsis et al., 2014).

The fossil described here was collected by locals working in the mines, rather than by paleontologists, complicating attempts to constrain stratigraphy and provenance. However, the pale white bone, and coarse grey matrix are typical of fossils from upper Couche III at Sidi Chennane.

Couche III contains an exceptional assemblage of fossil marine vertebrates. Marine reptiles, including diverse mosasaurid squamates (Bardet et al., 2004; Bardet et al., 2005a;

102 Bardet et al., 2005b; Bardet et al., 2008; Schulp et al., 2009; LeBlanc et al., 2012; Bardet et al., 2015), elasmosaurid (Vincent et al., 2011; Vincent et al., 2013), and chelonioid turtles (Bardet et al., 2013; Lapparent de Broin et al., 2013) dominate the community. Bony fishes and selachians (Arambourg, 1952) were diverse and abundant (see Bardet et al., 2017 for faunal list and references). Above, diverse pterosaurs exploited the seas (Pereda-Suberbiola et al., 2003; Longrich et al., 2018). Rare dinosaurs suggest a nearby terrestrial community (Pereda-Suberbiola et al., 2004; Longrich et al., 2017; Longrich et al., 2020).

110 Craton, was characterized by upwelling (Martin et al., 2017). Upwelling could explain the

111 high abundance, diversity and disparity of marine predators here (Martin et al., 2017). The 
112 Couche III assemblage may sample not just a diverse time in mosasaurid history, but a

113 uniquely diverse habitat — a biodiversity hot spot.

114

115

116 Abbreviations. MHNM Muséum d'Histoire naturelle de Marrakech, Université Cadi Ayyad,

117 Morocco; OCP, Office Chérifien des Phosphates, Morocco.

118

119

120

3. Results

121

122

3.1 Systematic paleontology

123

124

SQUAMATA Oppel (1811)

125

MOSASAURIDAE Gervais (1852)

126

MOSASAURINAE Gervais (1852)

127

128

Xenodens calminechari gen. et sp. nov.

129

130

Etymology. The genus name is derived from the Greek xenos, 'strange', and Latin dens,

131 'tooth'. The species name derives from the Arabic calminechari (كالمنشار), 'like a saw'.

Holotype. MHNM.KH.333 (Figs. 3-5)

134

135 Horizon and locality. Upper Maastrichtian of Sidi Chennane phosphate mines, Khouribga

136 Province, Morocco. Matrix and preservation are typical of Sidi Chennane, with a bleached 
white bone and pale, grey matrix characteristic of Couche III at Sidi Chennane (Fig. 3). The matrix is coarse, with a small fraction of fine particles, and contains teleost fragments. This coarse matrix is typical of fossils from upper Couche III at Sidi Chennane.

141 Diagnosis. Small mosasaurid (Figs. 6, 7). Anterior end of maxilla long and tapered in lateral 142 view, with premaxilla-maxilla suture forming an angle of $15^{\circ}$ with the dentigerous margin. 143 Premaxillary-maxillary suture extends posteriorly 6, perhaps 7 , tooth positions. At least 144 thirteen maxillary teeth. Marginal tooth crowns low, strongly laterally compressed, up to twice as long anteroposteriorly as broad labiolingually. Crowns with strongly convex anterior 146 surface bearing a cutting carina. Low apicobasal ridge along the anterior half of the crown 147 defining a shallow groove or gutter on lingual and labial surfaces. Tooth apex strongly 148 hooked posteriorly, behind the base of the crown, and posteriorly concave edge with an unserrated carina. Completely smooth enamel. Bases of crowns oriented obliquely relative to dentigerous margin of jaw in lateral view. Teeth closely packed to form a saw-like cutting edge. Roots of adjacent teeth expanded, fusing into a continuous ridge of dental bone.

152 Anteroposteriorly elongated replacement pits.

\subsection{Description}

Maxilla (Figs. 3, 4). The maxilla is small, measuring $100 \mathrm{~mm}$ in length. It is broken posteriorly; the jugal process may have extended another centimeter or two. At its apex it measures $26 \mathrm{~mm}$ and posteriorly it measures $20 \mathrm{~mm}$ tall.

The anterior end of the maxilla forms a concave groove for the premaxilla, such that

160 flanges of the maxilla clasped the premaxilla laterally and medially. The medial flange is 161 larger than the lateral flange. 
In lateral view, the maxilla's tip has an obtuse ' $\mathrm{v}$ ' shape where it contacted the

163

164

165

166

167

168

169

170

171

172

173

174

175

176

177

178

179

180

181

182

183

184

185

premaxilla, so that the premaxilla underlapped the maxilla ventrally and overlapped it dorsally. Anterodorsally the premaxillary contact is broadly convex, a feature shared with Clidastes and Mosasaurinae (Schulp et al., 2008). The suture continues posteriorly to form a long, straight contact with the premaxilla. This dorsal margin has a thin, sharp edge that would have contacted the premaxilla in a loose suture. The suture extends posteriorly to the sixth or perhaps seventh alveolus. A posteriorly extended suture is derived within mosasaurids. The suture extends as far as the third tooth position in Prognathodon spp. (Schulp et al., 2008) and Globidens cf. phosphaticus (Polcyn et al., 2010), as far as the fourth tooth in Globidens alabamensis (Gilmore, 1912) and Mosasaurus hoffmanni (LinghamSoliar, 1995), to the fifth or sixth tooth in Clidastes (Russell, 1967), and the sixth or seventh tooth in Halisaurus arambourgi (Bardet et al., 2005b). The suture lies at a low angle, about 15 degrees, relative to the maxilla's ventral margin. Posteriorly there is a large, concave embayment for the retracted external naris.

Ventral and posterior to the naris, the sutural contact for the prefrontal is preserved with its typical zigzag shape. Given the shape of this suture and its wide dorsal extension, the prefrontal probably participates in the naris.

The lateral surface of the maxilla, just dorsal to the gum line, is covered by neurovascular foramina corresponding to the terminal branches of the maxillary nerve, as is typical of mosasaurids (Fig. 4A) (Russell, 1967). These foramina are very small and numerous anteriorly, then become larger posteriorly and form a distinct line. The line is distinctly elevated above the maxilla's ventral margin, an unusual condition shared with Globidens alabamaensis (Gilmore, 1912) but not other Globidens (Polcyn et al., 2010), or other Mosasaurini. The elaboration of these foramina may be associated with the development of nerves for mechanoreptors (Martill et al., 2021), which similar to modern sea 
snakes (Crowe-Riddell et al., 2016; Crowe-Riddell et al., 2019), may have been used to sense water pressure.

In medial view, the dental parapet is deep posteriorly then strongly tapers anteriorly, being reduced to a low ridge at the anterior end (Fig. 4). It is sharp and distinctly separated from the body of the maxilla by a groove. Anteriorly, a low, thin, mediodorsally directed flange of bone lies just above the dental parapet. Just above this flange a large, oval foramen. The medial dental parapet appears slightly less developed ventrally than the lateral one. This character is seen in primitive mosasaurids such as Russellosaurus coheni (Polcyn and Bell, 2005) and Halisaurus arambourgi but also in Globidens spp. (Gilmore, 1912; Polcyn et al., 2010).

Positions for 13 teeth are preserved. Two or three more were probably present posteriorly where the maxilla is broken away.

Dentition. Tooth crowns (Fig. 5) are bladelike and labiolingually flattened to a degree not seen in other Mosasauridae, although this condition is approached in Carinodens (Schulp et al., 2009). Here the teeth are more like those of varanids or theropods than other mosasaurids, where teeth have a more conical shape. Crowns are low and trapezoidal in lateral view. There is a strongly convex, crescentic anterior margin with a sharp carina, a hooked apex, and a weakly concave posterior margin with an unserrated carina. Again, teeth are like those of Carinodens (Schulp et al., 2009) in being low and broad, with convex anterior edges. Enamel is totally smooth, and lacks the ornamentation seen in Carinodens (Schulp et al., 2009), Globidens (Bardet et al., 2005a; Polcyn et al., 2010), and some Prognathodon species (Konishi et al., 2011), where a rugose texture of coarse bumps and wrinkles extends down from the tooth apex. 

and Kearney, 2005) as in other Mosasauridae (Russell, 1967; Caldwell, 2007). In most Mosasauridae, e.g. Mosasaurus (Rieppel and Kearney, 2005) this pedicel is tall, but in Xenodens it is short, as in Carinodens and Globidens. Crowns do not sit perpendicular to the pedicel, as typical of Mosasauridae, and instead are slightly inclined backwards. The line formed by the base of the enamel therefore lies at an oblique angle to the jaw. This is another unusual feature shared with Carinodens (Schulp et al., 2009).

Tooth roots insert into thecae, formed laterally by the lingual margin of the maxilla,

medially by a ventrally extended, bony parapet of the maxilla, and anteriorly and posteriorly by septa formed of interdental bone (Rieppel and Kearney, 2005; Caldwell, 2007). Tooth roots are mediolaterally compressed and expanded anteroposteriorly so that adjacent roots contact each other and fuse to create a wall of bone supporting the teeth. This configuration is unique among squamates, with the exception of Carinodens, which shares these fused tooth bases (Schulp et al., 2009).

Tooth roots bear large replacement pits, as in most mosasaurids (Bell Jr, 1997; Rieppel and Kearney, 2005). These pits extend deep into the pedicel forming interdental crypts. The openings for these crypts are developed as anteroposteriorly elongate and narrow slots. A similar morphology is seen in Carinodens (LeBlanc et al., 2012), and to a much lesser degree, in Eremiasaurus (LeBlanc et al., 2012). These openings are displaced posteriorly relative to the crown, which seems to result from anterior displacement of the crown relative to the tooth root.

Teeth are closely packed, with a slight gap between the anterior carina of one tooth and the posterior carina of the other. A similar arrangement is seen in C. minalmamar (Schulp et al., 2009). The effect is to create a single, serrated cutting edge, like a sawblade. 
4. Discussion

238

\subsection{Affinities of Xenodens}

Despite the unusual morphology of the teeth of Xenodens, multiple characters allow confident referral to the Mosasauridae. These include a long, low, triangular maxilla, elongate premaxilla-maxilla contact, such that the naris would be posteriorly retracted; tooth crowns being borne on bony pedicels, tooth bases implanting into distinct thecae, and deep replacement pits developing as crypts.

The unique dental morphology and arrangement in Xenodens warrants recognition of a distinct genus and species. Several features suggest affinities with Carinodens, a specialized, durophagous mosasaurid. Three species of Carinodens have been described: Carinodens belgicus, from the upper Maastrichtian of Belgium and the Netherlands, C. minalmamar, from the upper Maastrichtian of Morocco, and C. palistinicus from Jordan (Kaddumi, 2009). Isolated teeth of Carinodens have been described from elsewhere (Schulp et al., 2009; Mulder et al., 2013; Milàn et al., 2018).

Teeth of Xenodens resemble Carinodens in many respects. These include (i) low, anteroposteriorly broad crowns, (ii) the strongly convex anterior carina, (iii) labiolingual compression of the crown. The teeth however differ from those of Carinodens in being posteriorly hooked, with sharp apices, and in being much more laterally compressed. The enamel is also completely smooth, unlike the sculpturing and sulci seen in both Carinodens species and particularly in C. belgicus, which in this feature is like that of Globidens. arrangement. Unlike other mosasaurids, (v) tooth crowns are obliquely oriented relative to 
the dental parapet in lateral view, (vi) tooth pedicels are anteroposteriorly expanded and

262

263

264

265

266

267

268

269

270

271

272

273

274

275

276

277

278

279

280 contacting, forming a continuous ridge of bone, and (vii) alveolar crypts are anteroposteriorly expanded in both genera.

Finally, (viii) the small reconstructed size of Xenodens and Carinodens and (xi) the relatively long, straight and low maxilla and high tooth count (mirroring the dentary of Carinodens) suggest affinities between the two.

Given that Carinodens is known from lower jaws and Xenodens from the upper, this poses the question of whether the two could come from one, heterodont animal. However, the shape, arrangement and ornamentation of the teeth in Xenodens being so distinct from Carinodens, it is unlikely they are the same species. Moreover, in mosasaurids as a whole, upper and lower teeth are so similar that it is difficult to determine whether teeth come from the upper or lower jaw (e.g. Russell, 1967, p 56-57). From a functional standpoint, pairing Xenodens-like upper teeth and Carinodens-like lower teeth is implausible since it would imply that upper and lower teeth functioned in radically different ways- one cutting softbodied prey, the other crushing armor. Different tooth functions are seen along the tooth row in squamates, and some species combine cutting and crushing teeth (e.g. Varanus niloticus). However, such variation is between anterior and posterior teeth, never (to our knowledge) uppers and lowers.

Apomorphies therefore identify Xenodens and Carinodens as a clade, exclusive of other mosasaurids. Beyond this, their relationships are unclear.

Carinodens has been allied with Globidens, in Globidensini (Schulp et al., 2004; Mulder et al., 2013; Milàn et al., 2018). The two genera share several adaptations, including a blunt tooth apex. C. belgicus also shares with Globidens rugose, ornate enamel (possibly absent in C. minalmamar) and both Carinodens species share the characteristic sulci present 
in some Globidens (Schulp et al., 2009). Blunt crowns and rugose, anastomosing enamel

287

288

289

290

291

292

293

294

295

296

297

298

299

300

301

302

303

304

305

306

307

308

309

texture are also seen in some species of Prognathodon including $P$. currii where it is pronounced (Schulp, 2006). Carinodens and Globidens also share extreme heterodonty, with anterior teeth reduced, and middle teeth greatly enlarged. Blunt, inflated tooth crowns and rugose enamel are adaptations for durophagy (Schulp et al., 2004).

However, such characters are highly homoplastic. Blunt teeth and heterodonty evolved repeatedly in durophagous squamates. Molariform teeth are found in the caiman lizard Dracaena (Teiidae) (Dalrymple, 1979), the Nile monitor, Varanus niloticus (Varanidae) (D'Amore, 2015), the scincid Tiliqua scincoides (Scincidae) (Estes and Williams, 1984), the anguid Diploglossus crusculus (Anguidae) (Estes and Williams, 1984). It also evolved independently in the amphisbaenians Trogonophis (Trogonophidae) (Westphal et al., 2019) and Amphisbaena ridleyi (Amphisbaenidae) (Pregill, 1984). Molariform teeth are also found in extinct lizards such as Odaxosaurus piger (Anguidae) (Pregill, 1984) and Chromatogenys tiliqoides (Scincidae) (Makádi and Nydam, 2015).

Ridged enamel is also seen in taxa with molariform teeth, including Tiliqua, Diploglossus, and Odaxosaurus. These features -molariform teeth, heterodonty, and enamel ridges- form a suite of functionally correlated characters that evolved repeatedly in durophagous lizards. Even within Mosasauroidea, durophagy likely evolved multiple times once in the lineage leading to Globidens, again within Prognathodon, and in the basal mosasauroid Coniasaurus (Caldwell and Cooper, 1999).

This does not prove that these features are convergent but suggests caution in using homoplastic characters. The absence of durophagous adaptations in Xenodens shows these characters are homoplastic even in Carinodens-like mosasaurids. If Xenodens and Carinodens are related, then durophagous adaptations were either lost in Xenodens (and absence of durophagy is a reversal) or independently gained in Carinodens from a non- 
311 durophagous common ancestor (and durophagy in Carinodens and Globidens are

312 convergent).

313 Last, there are differences between the jaws of Carinodens-like mosasaurids and

314 Globidensini. Carinodens has a longer, more slender, straighter mandible than Globidens and

315 Prognathodon, where it is short, deep, and bowed (Lingham-Soliar and Nolf, 1989; Polcyn et

316 al., 2010; Konishi et al., 2011). The low, triangular maxilla of Xenodens and Carinodens also

317 differs from Globidens and Prognathodon (ibid). Instead, the long, low profile of the maxilla

318 and elongate premaxilla-maxilla suture are like Mosasaurini. Strikingly, postcrania described

319 for Carinodens (Kaddumi, 2009) show the short, broad first metacarpal and phalanges of

320 digit I with anterior processes on their proximal and distal ends, giving them a 'butterfly'

321 appearance. Such processes are well-developed on the first manus and pes digits in

322 Mosasaurus and Plotosaurus (Russell, 1967; Lingham-Soliar, 1995; Lindgren et al., 2008)

323 but not in other Mosasauridae, suggesting that Carinodens (and by extension, Xenodens) are

324 part of Mosasaurini.

325 Only the swollen tooth crown seems to connect Xenodens to the Globidensini, though

326 this character is weakly developed compared to Globidens, Carinodens and Prognathodon

327 (Schulp et al., 2004).

328 The elevated medial parapet of the dentary and the well-developed tooth crypts are

329 both derived features, shared with Mosasaurinae and Tylosaurinae and absent in Halisaurinae

330 (Schulp et al., 2004). Beyond this, few features are available to resolve the higher-level

331 affinities of the Carinodens-Xenodens group.

332

333

334

4.2 Function and Ecology 
336 The unusual dental battery of Xenodens indicates a specialized feeding mode. Mosasaurid

337 teeth as a whole present a common Bauplan, generally being conical in cross-section,

338 homodont to weakly heterodont, and widely spaced (Russell, 1967). The "standard" or

339 default plesiomorphic mosasaurid teeth are small, acutely conical hooks, like those of

340 Tethysaurus, (Bardet et al., 2003), Russellosaurus (Polcyn and Bell, 2005), and Halisaurus

341 (Bardet et al., 2005b). Such teeth are suitable for piercing small prey, indicating a diet of small prey like fish and soft-bodied invertebrates such as cephalopods.

However, over the course of the Late Cretaceous, mosasaurid teeth evolved a wide

range of morphologies, suitable for piercing and holding (Halisaurus, Plioplatecarpus,

Clidastes, etc.), piercing and cutting (Mosasaurus, Tylosaurus, etc.) or crushing (Globidens,

Prognathodon currii, Carinodens, etc.), following the morphoguilds defined by Massare

347 (Massare, 1987).

In some species, such as Eremiasaurus heterodontus (LeBlanc et al., 2012) and Mosasaurus hoffmanni (Lingham-Soliar, 1995) (Lingham-Soliar and Nolf, 1989), marginal teeth are large, laterally compressed, and serrated. This morphology is likely effective for seizing and tearing apart large prey. A similar morphology is seen in some varanids, such as Varanus acanthurus. lesser degree, Prognathodon currii (Christiansen and Bonde, 2002) lateral teeth are large, straight, with blunt apices, and low, bulbous crowns. These adaptations facilitate crushing of hard prey, either shelled invertebrates or bony vertebrates. Ornament in the form of bumps and ridges is well-developed on the enamel.

Tooth form and arrangement in Xenodens are different from any previously described morphology. Teeth are laterally compressed and bladelike to a degree unlike any other mosasaurid or squamate. Crowns are low and rectangular, the apex is hooked, and carinae are 
sharp but unserrated. Crowns are closely packed, leaving narrow slots between adjacent

362

363

crowns. The tooth arrangement creates a slotted saw blade, similar to a circular saw. There is no similar arrangement in any other mosasaurid or lizard, or to our knowledge, any other tetrapod.

Surprisingly, a similar arrangement is seen in sharks, specifically dogfish (Squaliformes) (Fig. 8). Here, low, hooked, bladelike teeth are packed in a row to form a cutting blade (Underwood et al., 2016). This arrangement is seen in upper and lower jaws of most dogfish (Squalidae) and in the lower jaws of gulper sharks (Centrophoridae), sleeper sharks (Somniosidae) and lantern sharks (Etmophoridae) (Underwood et al., 2016). A sawblade is also seen in piranhas, the pycnodont Serrasalmimus (Vullo et al., 2017), and the squalimorph Isistius (cookiecutter shark) (Underwood et al., 2016) but these fishes differ in that they have fewer and larger teeth, and the crowns are taller and more triangular.

In dogfish sharks, the jaws apparently function as cutting blades. Long-axis roll of the jaws, a 'head shake' (Wilga and Motta, 1998) is used to saw prey in half. The bladelike lower teeth of Pacific sleeper sharks (Somniosus pacificus) allow them to gouge huge, hemispherical bolts of flesh from prey, as seen in large halibut caught on long line gear (NRL pers. obs.). The specialized cutting blades seen in Squaliformes therefore seem to be an adaptation allowing for relatively small predators to feed on proportionately large prey.

Despite these specializations, Squaliformes have broad diets, and take a range of food. Squalus acanthias feeds on fish, crustaceans, mollusks, nematodes and sea anemones (Jones and Geen, 1977; Avsar, 2001). Dogfish also scavenge on marine mammals (Bigelow, 1994). Rather than limiting the diet, specialized jaws and teeth seem to expand the range of prey, and may allow small sharks to feed on larger prey items than would otherwise be possible. Similarly, the piranha's bladelike teeth are effective for eating meat but piranhas also take fruit and nuts (Prudente et al., 2016). 

prey. Given the animal's small estimated size, prey likely included small invertebrates such

388 as crustaceans and cephalopods, fish, and potentially, larger prey items, including large fish and cephalopods, or scavenging of large mosasaurids and plesiosaurs (Fig. 9).

So far, Xenodens appears to be rare in the fauna, but given the abundance of isolated mosasaur teeth in the phosphates, it is likely that teeth are present in the assemblage but misidentified as shark teeth. Xenodens teeth can be distinguished from other mosasaurids by their distinctive shape. Shed Xenodens teeth could readily be distinguished from shark's teeth by the absence of a root, and a basal resorption pit, which are characteristic of shed mosasaurid teeth.

\section{Conclusions.}

A new mosasaurid, Xenodens calminechari gen. et sp. nov., is represented by a small upper jaw from the upper Maastrichtian phosphates of Morocco. The new mosasaurid exhibits a dentition that is not just unique among mosasaurids, but among tetrapods, with bladelike teeth closely packed to form a serrated cutting surface. Some sharks convergently evolved similar dentition (Underwood et al., 2016), suggesting that the jaws of Xenodens were used to carve apart large prey items. Regardless of the jaw's precise function, the unusual dental morphology of Xenodens suggests a feeding strategy that was unique among mosasaurids or other marine tetrapods. Along with other specialized morphologies in mosasaurids - the button-shaped, crushing teeth of Carinodens and Globidens, the peg-like teeth of Prognathodon currii, bladelike teeth in Eremiasaurus, or the conical, orca-like teeth in large Prognathodon sp. - the teeth of Xenodens expand the remarkable functional and ecological diversity of late Maastrichtian mosasaurids, especially in the African Tethys (Bardet et al., 2015; Bardet et al., 2017). Insofar as predator diversity is driven by abundance and diversity 
411 of prey, high mosasaurid diversity prior to the K-Pg extinction suggests a diverse, stable

412 marine ecosystem, cut down in its prime by the Chicxulub impact.

413

414

415 Acknowledgements

416

417 Thanks to Mustapha Meharich and Mohammed Ben Sekkou for assistance to NRL in 418 Morocco, to Charlie Underwood for discussions of shark dentition, and to Ross Robertson for 419 photographs. Finally, thanks to Dmitry Grigoriev (Saint Petersburg, Russia) and an 420 anonymous reviewer for their time and helpful reviews. 
423 Arambourg, C., 1935. Note préliminaire sur les vertébrés fossiles des phosphates du Maroc.

424 Bulletin de la Société géologique de France 5, 413-439.

425 Arambourg, C., 1952. Les vertébrés fossiles des gisements de phosphates (Maroc-Algérie-

426 Tunisie). Notes et Mémoires du Service Géologique du Maroc. 92, 1-372.

427 Avsar, D., 2001. Age, growth, reproduction and feeding of the spurdog (Squalus acanthias

428 Linnaeus, 1758) in the South-eastern Black Sea. Estuarine, Coastal and Shelf Science 52,

$429269-278$.

430 Bardet, N., Falconnet, J., Fischer, V., Houssaye, A., Jouve, S., Pereda-Suberbiola, X., Perez-

431 García, A., Rage, J.-C., Vincent, P., 2014. Mesozoic marine reptile palaeobiogeography in

432 response to drifting plates. Gondwana Research 26, 869-887.

433 Bardet, N., Gheerbrant, E., Noubhani, A., Cappetta, H., Jouve, S., Bourdon, E., Pereda434 Suberbiola, X., Jalil, N.-E., Vincent, P., Houssaye, A., Solé, F., El Houssaini Darif, K., 435 Adnet, S., Rage, J.-C., Lapparent de Broin de, F., Sudre, J., Bouya, B., Amaghzaz, M., 436 Meslouh, S., 2017. Les Vertébrés des phosphates crétacés-paléogènes (72, 1-47, $8 \mathrm{Ma})$ du 437 Maroc, Mémoires de la Société Géologique de France N.S. 180, pp. 351-452.

438 Bardet, N., Houssaye, A., Vincent, P., Pereda-Suberbiola, X., Amaghzaz, M., Jourani, E., 439 Meslouh, S., 2015. Mosasaurids (Squamata) from the Maastrichtian phosphates of Morocco: 440 biodiversity, palaeobiogeography and palaeoecology based on tooth morphoguilds.

441 Gondwana Research 27, 1068-1078.

442 Bardet, N., Jalil, N.-E., Broin, F.d.L.d., Germain, D., Lambert, O., Amaghzaz, M., 2013. A

443 Giant Chelonioid Turtle from the Late Cretaceous of Morocco with a Suction Feeding

444 Apparatus Unique among Tetrapods. PLoS ONE 8, e63586.

445 Bardet, N., Pereda-Suberbiola, X., Iarochène, M., Amalik, M., Bouya, B., 2005a.

446 Durophagous Mosasauridae (Squamata) from the Upper Cretaceous phosphates of Morocco, 447 with description of a new species of Globidens. Netherlands Journal of Geosciences 84, 167.

448 Bardet, N., Pereda-Suberbiola, X., Iarochène, M., Bouya, B., Amaghzaz, M., 2005b. A new 449 species of Halisaurus from the Late Cretaceous phosphates of Morocco, and the 450 phylogenetical relationships of the Halisaurinae (Squamata: Mosasauridae). Zoological 451 Journal of the Linnean Society 143, 447-472.

452 Bardet, N., Pereda-Suberbiola, X., Iarochène, M., Bouyahyaoui, F., Bouya, B., Amaghzaz, 453 M., 2004. Mosasaurus beaugei Arambourg, 1952 (Squamata, Mosasauridae) from the Late 454 Cretaceous phosphates of Morocco. Geobios 37, 315-324. 
455

456

457

458

459

460

461

462

463

464

465

466

467

468

469

470

471

472

473

474

475

476

477

478

479

480

481

482

483

484

485

486

487

488

Bardet, N., Pereda-Suberbiola, X., Jalil, N.-E., 2003. A new mosasauroid (Squamata) from the Late Cretaceous (Turonian) of Morocco. Comptes Rendus Palevol 2, 607-616.

Bardet, N., Pereda-Suberbiola, X., Jouve, S., Bourdon, E., Vincent, P., Houssaye, A., Rage, J.-C., Jalil, N.-E., Bouya, B., Amaghzaz, M., 2010. Reptilian assemblages from the latest Cretaceous-Palaeogene phosphates of Morocco: from Arambourg to present time. Historical Biology 22, 186-199.

Bardet, N., Pereda-Suberbiola, X., Schulp, A.S., Bouya, B., 2008. New material of Carinodens (Squamata, Mosasauridae) from the Maastrichtian (Late Cretaceous) phosphates of Morocco, Proceedings of the Second Mosasaur Meeting. Fort Hays Studies, Special, pp. 29-36.

Bell Jr, G.L., 1997. A phylogenetic revision of North American and Adriatic Mosasauroidea, Ancient marine reptiles. Elsevier, pp. 293-332.

Bigelow, P.K., 1994. Occurrence of a squaloid shark (Chondrichthyes: Squaliformes) with the pinniped Allodesmus from the upper Miocene of Washington. Journal of Paleontology 68, 680-684.

Caldwell, M.W., 2007. Ontogeny, anatomy and attachment of the dentition in mosasaurs (Mosasauridae: Squamata). Zoological Journal of the Linnean Society 149, 687-700.

Caldwell, M.W., Cooper, J.A., 1999. Redescription, palaeobiogeography and palaeoecology of Coniasaurus crassidens OWEN, 1850 (Squamata) from the Lower Chalk (Cretaceous; Cenomanian) of SE England. Zoological Journal of the Linnean Society 127, 423-452.

Cappetta, H., 1987. Chondrichthyes II. Mesozoic and Cenozoic Elasmobranchii. Handbook of paleoichthyology 3, 1-193.

Cappetta, H., Bardet, N., Pereda-Suberbiola, X., Adnet, S., Akkrim, D., Amalik, M., Benabdallah, A., 2014. Marine vertebrate faunas from the Maastrichtian phosphates of Benguérir (Ganntour Basin, Morocco): Biostratigraphy, palaeobiogeography and palaeoecology. Palaeogeography, palaeoclimatology, palaeoecology 409, 217-238.

Christiansen, P., Bonde, N., 2002. A new species of gigantic mosasaur from the Late Cretaceous of Israel. Journal of Vertebrate Paleontology 22, 629-644.

Crowe-Riddell, J.M., Snelling, E.P., Watson, A.P., Suh, A.K., Partridge, J.C., Sanders, K.L., 2016. The evolution of scale sensilla in the transition from land to sea in elapid snakes. Open biology 6, 160054.

Crowe-Riddell, J.M., Williams, R., Chapuis, L., Sanders, K.L., 2019. Ultrastructural evidence of a mechanosensory function of scale organs (sensilla) in sea snakes (Hydrophiinae). Royal Society open science 6, 182022. 
489 D'Amore, D.C., 2015. Illustrating ontogenetic change in the dentition of the Nile monitor

490 lizard, Varanus niloticus: a case study in the application of geometric morphometric methods

491 for the quantification of shape-size heterodonty. Journal of Anatomy 226, 403-419.

492 Dalrymple, G.H., 1979. On the jaw mechanism of the snail-crushing lizards, Dracaena

493 Daudin 1802 (Reptilia, Lacertilia, Teiidae). Journal of Herpetology, 303-311.

494 Estes, R., Williams, E.E., 1984. Ontogenetic variation in the molariform teeth of lizards.

495 Journal of Vertebrate Paleontology 4, 96-107.

496 Everhart, M.J., 2001. Revisions to the biostratigraphy of the Mosasauridae (Squamata) in the 497 Smoky Hill Chalk member of the Niobrara Chalk (Late Cretaceous) of Kansas. Transactions 498 of the Kansas Academy of Science 104, 59-78.

499 Gervais, P., 1852. Zoologie et paléontologie françaises (animaux vertébrés): nouvelles 500 recherches sur les animaux vivants del la France. Arthus Bertrand.

501 Gilmore, C.W., 1912. A new mosasauroid reptile from the Cretaceous of Alabama. 502 Proceedings of the United States National Museum 41, 479-484.

503 Holwerda, F., Beatty, B., Schulp, A., 2013. Dental macro-and microwear in Carinodens 504 belgicus, a small mosasaur from the type Maastrichtian. Netherlands Journal of Geosciences 505 92, 267-274.

506 Jones, B.C., Geen, G.H., 1977. Food and feeding of spiny dogfish (Squalus acanthias) in 507 British Columbia waters. Journal of the Fisheries Board of Canada 34, 2056-2066.

508 Kaddumi, H.F., 2009. The first and most complete Carinodens (Squamata: Mosasauridae) 509 skeleton yet with a description of a new species from the Harrana Fauna, Fossils of the 510 Harrana Fauna and the Adjacent Areas. Publications of the Eternal River Museum of Natural 511 History Amman, pp. 49-64.

512 Kocsis, L., Gheerbrant, E., Mouflih, M., Cappetta, H., Yans, J., Amaghzaz, M., 2014.

513 Comprehensive stable isotope investigation of marine biogenic apatite from the Late

514 Cretaceous-Early Eocene phosphate series of Morocco. Palaeogeography,

515 Palaeoclimatology, Palaeoecology 394, 74-88.

516 Konishi, T., Brinkman, D., Massare, J.A., Caldwell, M.W., 2011. New exceptional specimens 517 of Prognathodon overtoni (Squamata, Mosasauridae) from the upper Campanian of Alberta, 518 Canada, and the systematics and ecology of the genus. Journal of Vertebrate Paleontology 31, 519 1026-1046.

520 Lapparent de Broin, F.d., Bardet, N., Amaghzaz, M., Meslouh, S., 2013. A strange new

521 chelonioid turtle from the Latest Cretaceous phosphates of Morocco. Comptes Rendus

522 Palevol 13, 87-95. 
523

524

525

526

527

528

529

530

531

532

533

534

535

536

537

538

539

540

541

542

543

544

545

546

547

548

549

550

551

552

553

554

555

556

557

LeBlanc, A.R., Mohr, S.R., Caldwell, M.W., 2019. Insights into the anatomy and functional morphology of durophagous mosasaurines (Squamata: Mosasauridae) from a new species of Globidens from Morocco. Zoological Journal of the Linnean Society 186, 1026-1052.

LeBlanc, A.R.H., Caldwell, M.W., Bardet, N., 2012. A new mosasaurine from the Maastrichtian (Upper Cretaceous) phosphates of Morocco and its implications for mosasaurine systematics. Journal of Vertebrate Paleontology 32, 82-104.

Lindgren, J., Caldwell, M.W., Jagt, J.W., 2008. New data on the postcranial anatomy of the California mosasaur Plotosaurus bennisoni (Camp, 1942)(Upper Cretaceous: Maastrichtian), and the taxonomic status of P. tuckeri (Camp, 1942). Journal of Vertebrate Paleontology 28, 1043-1054.

Lindgren, J., Kaddumi, H.F., Polcyn, M.J., 2013. Soft tissue preservation in a fossil marine lizard with a bilobed tail fin. Nature Communications 4, 1-8.

Lindgren, J., Polcyn, M.J., Young, B.A., 2011. Landlubbers to leviathans: evolution of swimming in mosasaurine mosasaurs. Paleobiology 37, 445-469.

Lingham-Soliar, T., 1995. Anatomy and functional morphology of the largest marine reptile known, Mosasaurus hoffmanni (Mosasauridae, Reptilia) from the Upper Cretaceous, Upper Maastrichtian of the Netherlands. Philosophical Transactions of the Royal Society of London. Series B: Biological Sciences 347, 155-180.

Lingham-Soliar, T., Nolf, D., 1989. The mosasaur Prognathodon (Reptilia, Mosasauridae) from the Upper Cretaceous of Belgium. Bulletin de l'Institut royal des Sciences naturelles de Belgique, Sciences de la Terre 59, 137-190.

Longrich, N.R., Martill, D.M., Andres, B., 2018. Late Maastrichtian pterosaurs from North Africa and mass extinction of Pterosauria at the Cretaceous-Paleogene boundary. PLoS Biology 16, e2001663.

Longrich, N.R., Pereda-Suberbiola, X., Jalil, N.-E., Khaldoune, F., Jourani, E., 2017. An abelisaurid from the latest Cretaceous (late Maastrichtian) of Morocco, North Africa. Cretaceous Research 76, 40-52.

Longrich, N.R., Pereda-Suberbiola, X., Pyron, R.A., Jalil, N.-E., 2020. The first duckbill dinosaur (Hadrosauridae: Lambeosaurinae) from Africa and the role of oceanic dispersal in dinosaur biogeography. Cretaceous Research, 104678.

Makádi, L., Nydam, R.L., 2015. A new durophagous scincomorphan lizard genus from the Late Cretaceous Iharkút locality (Hungary, Bakony Mts). Paläontologische Zeitschrift 89, 925-941.

Martill, D.M., Smith, R.E., Longrich, N., Brown, J., 2021. Evidence for tactile foraging in pterosaurs: a sensitive tip to the beak of Lonchodraco giganteus (Pterosauria, 

104637.

560 Martin, J.E., Vincent, P., Tacail, T., Khaldoune, F., Jourani, E., Bardet, N., Balter, V., 2017.

561 Calcium isotopic evidence for vulnerable marine ecosystem structure prior to the $\mathrm{K} / \mathrm{Pg}$

562 extinction. Current Biology 27, 1641-1644. e1642.

563 Massare, J.A., 1987. Tooth morphology and prey preference of Mesozoic marine reptiles.

564 Journal of Vertebrate Paleontology 7, 121-137.

565 Milàn, J., Jagt, J.W., Lindgren, J., Schulp, A.S., 2018. First record of Carinodens (Squamata, 566 Mosasauridae) from the uppermost Maastrichtian of Stevns Klint, Denmark. Alcheringa: An

567 Australasian Journal of Palaeontology 42, 597-602.

568 Mulder, E., Formanoy, P., Gallagher, W., Jagt, J., Schulp, A., 2013. The first North American 569 record of Carinodens belgicus (Squamata, Mosasauridae) and correlation with the youngest

570 in situ examples from the Maastrichtian type area: palaeoecological implications.

571 Netherlands Journal of Geosciences 92, 145-152.

572 Oppel, M., 1811. Die ordnungen, familien und gattungen der reptilien als prodrom einer

573 naturgeschichte derselben. Lindauer.

574 Pereda-Suberbiola, X., Bardet, N., Iarochène, M., Bouya, B., Amaghzaz, M., 2004. The first 575 record of a sauropod dinosaur from the Late Cretaceous phosphates of Morocco. Journal of

576 African Earth Sciences 40, 81-88.

577 Pereda-Suberbiola, X., Bardet, N., Jouve, S., Iarochène, M., Bouya, B., Amaghzaz, M., 2003. 578 A new azhdarchid pterosaur from the Late Cretaceous phosphates of Morocco. Geological

579 Society, London, Special Publications 217, 79-90.

580 Polcyn, M.J., Bell, G.L., 2005. Russellosaurus coheni n. gen., n. sp., a 92 million-year-old 581 mosasaur from Texas (USA), and the definition of the parafamily Russellosaurina.

582 Netherlands Journal of Geosciences 84, 321-333.

583 Polcyn, M.J., Jacobs, L.L., Araújo, R., Schulp, A.S., Mateus, O., 2013. Physical drivers of 584 mosasaur evolution. Palaeogeogr Palaeoclim Palaeoecol.

585 Polcyn, M.J., Jacobs, L.L., Schulp, A.S., Mateus, O., 2010. The North African Mosasaur 586 Globidens phosphaticus from the Maastrichtian of Angola. Historical Biology 22, 175-185.

587 Pregill, G., 1984. Durophagous feeding adaptations in an amphisbaenid. Journal of 588 Herpetology, 186-191.

589 Prudente, B.d.S., Carneiro-Marinho, P., Valente, R.d.M., Montag, L.F.d.A., 2016. Feeding 590 ecology of Serrasalmus gouldingi (Characiformes: Serrasalmidae) in the lower Anapu River 591 region, eastern Amazon, Brazil. Acta Amazonica 46, 259-270. 
592 Rieppel, O., Kearney, M., 2005. Tooth replacement in the Late Cretaceous mosasaur

593 Clidastes. Journal of Herpetology 39, 688-692.

594 Rothschild, B., Martin, L.D., 1987. Avascular necrosis: occurrence in diving Cretaceous 595 mosasaurs. Science 236, 75-77.

596 Russell, D., 1967. Systematics and morphology of American mosasaurs. Bulletin of the 597 Peabody Museum of Natural History 23, 1-240.

598 Schulp, A., 2006. A comparative description of Prognathodon saturator (Mosasauridae, 599 Squamata), with notes on its phylogeny. On Maastricht Mosasaurs, 19-56.

600 Schulp, A., Vonhof, H., Van der Lubbe, J., Janssen, R., Van Baal, R., 2013. On diving and 601 diet: resource partitioning in type-Maastrichtian mosasaurs. Netherlands Journal of 602 Geosciences 92, 165-170.

603 Schulp, A.S., Bardet, N., Bouya, B., 2009. A new species of the durophagous mosasaur 604 Carinodens (Squamata, Mosasauridae) and additional material of Carinodens belgicus from 605 the Maastrichtian phosphates of Morocco. Netherlands Journal of Geosciences 88, 161-167.

606 Schulp, A.S., Jagt, J.W., Fonken, F., 2004. New material of the mosasaur Carinodens 607 belgicus from the Upper Cretaceous of The Netherlands. Journal of Vertebrate Paleontology 608 24, 744-747.

609 Schulp, A.S., Polcyn, M.J., Mateus, O., Jacobs, L.L., Morais, M.L., 2008. A new species of 610 Prognathodon (Squamata, Mosasauridae) from the Maastrichtian of Angola, and the 611 affinities of the mosasaur genus Liodon, Proceedings of the Second Mosasaur Meeting, Fort 612 Hays Studies Special Issue, pp. 1-12.

613 Strong, C.R., Caldwell, M.W., Konishi, T., Palci, A., 2020. A new species of longirostrine 614 plioplatecarpine mosasaur (Squamata: Mosasauridae) from the Late Cretaceous of Morocco, 615 with a re-evaluation of the problematic taxon 'Platecarpus' ptychodon. Journal of Systematic 616 Palaeontology, 1-36.

617 Underwood, C., Johanson, Z., Smith, M.M., 2016. Cutting blade dentitions in squaliform 618 sharks form by modification of inherited alternate tooth ordering patterns. Royal Society 619 open science 3, 160385.

620 Vincent, P., Bardet, N., Houssaye, A., Amaghzaz, M., Meslouh, S., 2013. New plesiosaur 621 specimens from the Maastrichtian Phosphates of Morocco and their implications for the 622 ecology of the latest Cretaceous marine apex predators. Gondwana Research 24, 796-805.

623 Vincent, P., Bardet, N., Pereda Suberbiola, X., Bouya, B., Amaghzaz, M., Meslouh, S., 2011.

624 Zarafasaura oceanis, a new elasmosaurid (Reptilia: Sauropterygia) from the Maastrichtian

625 Phosphates of Morocco and the palaeobiogeography of latest Cretaceous plesiosaurs.

626 Gondwana Research 19, 1062-1073. 
627 Vullo, R., Cavin, L., Khalloufi, B., Amaghzaz, M., Bardet, N., Jalil, N.-E., Jourani, E.,

628 Khaldoune, F., Gheerbrant, E., 2017. A unique Cretaceous-Paleogene lineage of piranha-

629 jawed pycnodont fishes. Scientific reports 7, 1-9.

630 Watwood, S.L., Miller, P.J., Johnson, M., Madsen, P.T., Tyack, P.L., 2006. Deep $\square$ diving

631 foraging behaviour of sperm whales (Physeter macrocephalus). Journal of Animal Ecology

$63275,814-825$.

633 Westphal, N., Mahlow, K., Head, J.J., Müller, J., 2019. Pectoral myology of limb-reduced

634 worm lizards (Squamata, Amphisbaenia) suggests decoupling of the musculoskeletal system

635 during the evolution of body elongation. BMC evolutionary biology 19, 1-23.

636 Wilga, C., Motta, P., 1998. Conservation and variation in the feeding mechanism of the spiny

637 dogfish Squalus acanthias. Journal of Experimental Biology 201, 1345-1358.

638 Woodward, A.S., 1891. III.--Note on tooth of an extinct Alligator (Bottosaurus belgicus, sp.

639 nov.) from the Lower Danian of Ciply, Belgium. Geological Magazine 8, 114-115. 


\section{Table 1}

642 List of Mosasauridae from the Phosphates of the Oulad Abdoun Basin, Morocco, upper

643 Couche III, latest Maastrichtian. Modified from Bardet et al. (2017)

644

645

646 Mosasaurinae

647

Mosasaurus beaugei Arambourg, 1952

648

Eremiasaurus heterodontus LeBlanc et al., 2012

649

Prognathdon aff. currii Christiansen \& Bonde, 2002

650

Prognathodon aff. saturator

651

Globidens cf. phosphaticus Bardet \& Pereda Suberbiola, 2005

652

Carinodens minalmamar Schulp et al., 2009

653

Carinodens belgicus (Woodward, 1891)

654

Xenodens calminechari new genus and species

655

656

657 Plioplatecarpinae

658

Gavialimimus almaghribensis, Strong et al. 2020

659

660

661 Halisaurinae

662

Halisaurus arambourgi Bardet \& Pereda Suberbiola, 2005a

663

664

665 
666

667 
669

670

671

672 Fig. 1. Map of Northern Morocco showing the location of the Sidi Chennane phosphate 673 mines in the Khouribga region.

674

675

676

677 Fig. 2. Stratigraphic column of Sidi Chennane, Khouribga Province, showing the 678 stratigraphic occurrence of Xenodens. Stratigraphic column after Kocsis et al. (2014).

679

680

681

682 Fig. 3. MHNM.KH.331, Xenodens calminechari new genus and species, holotype left 683 maxilla in matrix. Maastrichtian, Sidi Chennane, Oulad Abdoun Basin, Khouribga province, 684 Morocco.

685

686

687

688

Fig. 4. MHNM.KH.331, Xenodens calminechari new genus and species. Maastrichtian, Sidi

689

Chennane, Oulad Abdoun Basin, Khouribga Province, Morocco. Holotype left maxilla, in 690 lateral (A), ventral (B), medial (C), and dorsal (D) views.

691 
693

694 Fig. 5. MHNM.KH.331, dentition of Xenodens calminechari new genus and species. 695 Maastrichtian, Sidi Chennane, Oulad Abdoun Basin, Khouribga Province, Morocco. In 696 medial (A), lateral (B) and occlusal (C) views.

697

698 Fig. 6. Reconstruction of the skull of Xenodens calminechari, after Mosasaurus hoffmanni 699 (Lingham-Soliar, 1995).

700

701 Fig. 7. Silhouette showing approximate size of Xenodens calminechari, with Homo sapiens 702 for scale. Scale bar $=1$ meter.

703

704 Fig. 8. Dogfish shark, Squalus acanthias, upper and lower teeth. Note teeth arranged in 705 serrated cutting blades. Courtesy Ross Robertson, Smithsonian Tropical Research Institute.

706

707 Figure 9. Reconstruction of Xenodens calminechari scavenging a carcass of the elasmosaurid 708 Zarafasaura oceanis. Artwork by Andrey Atuchin, 2020. 

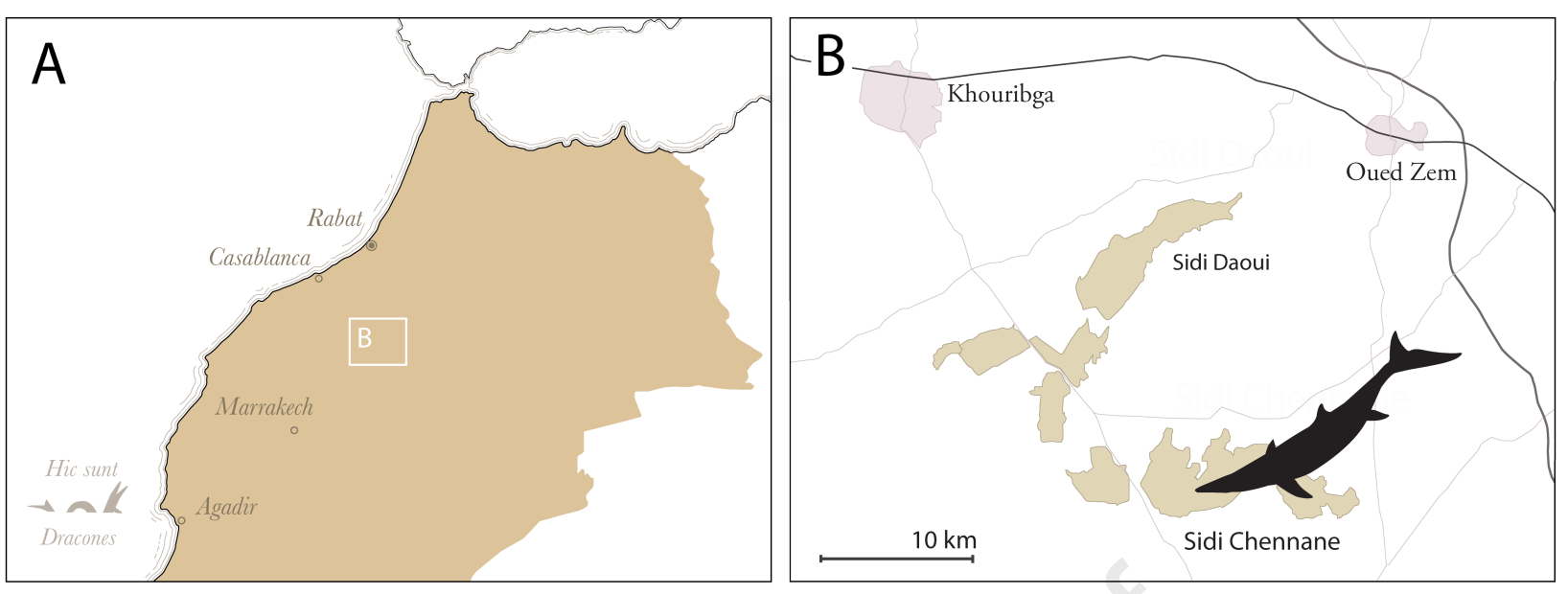


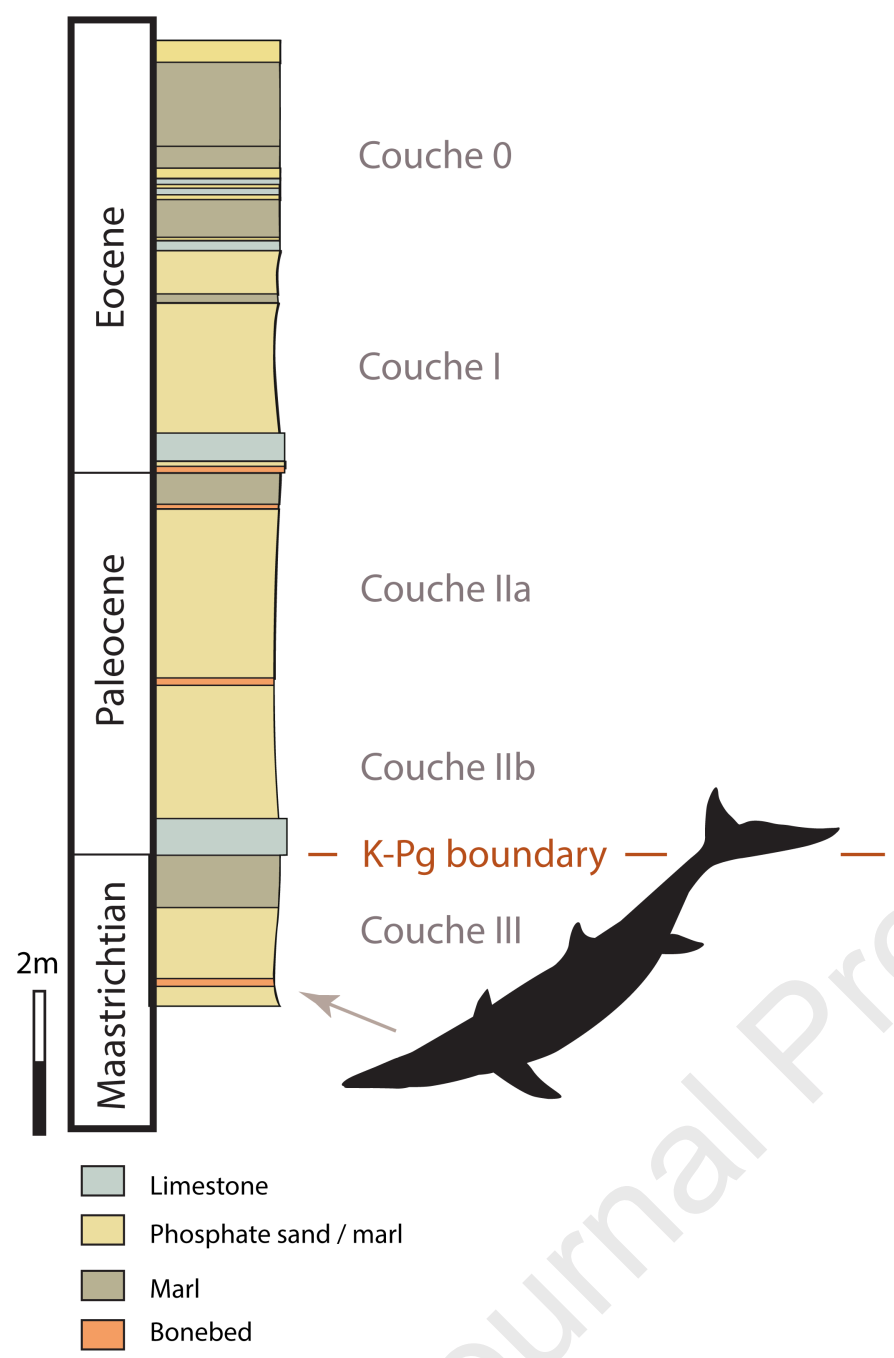




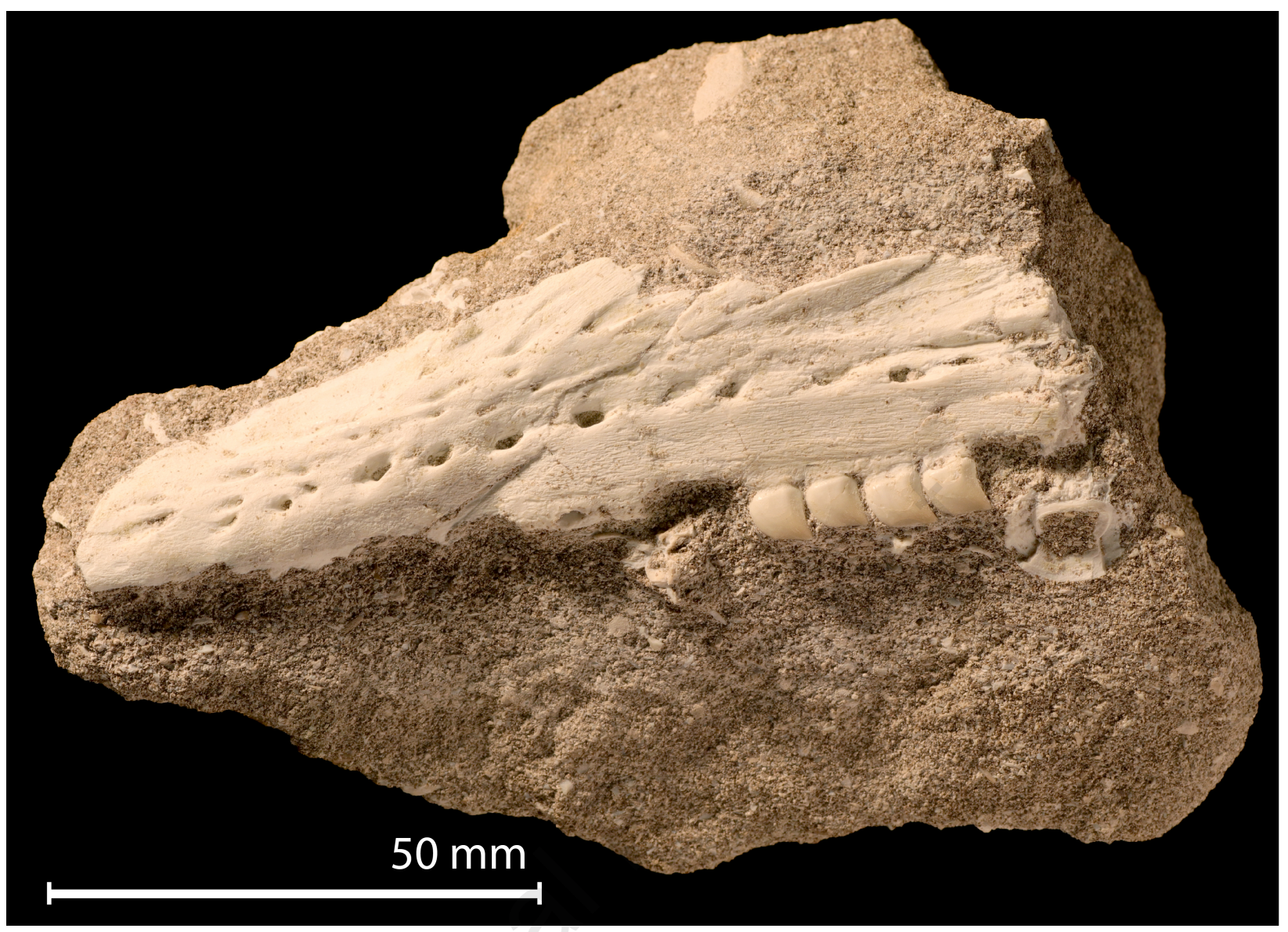


A

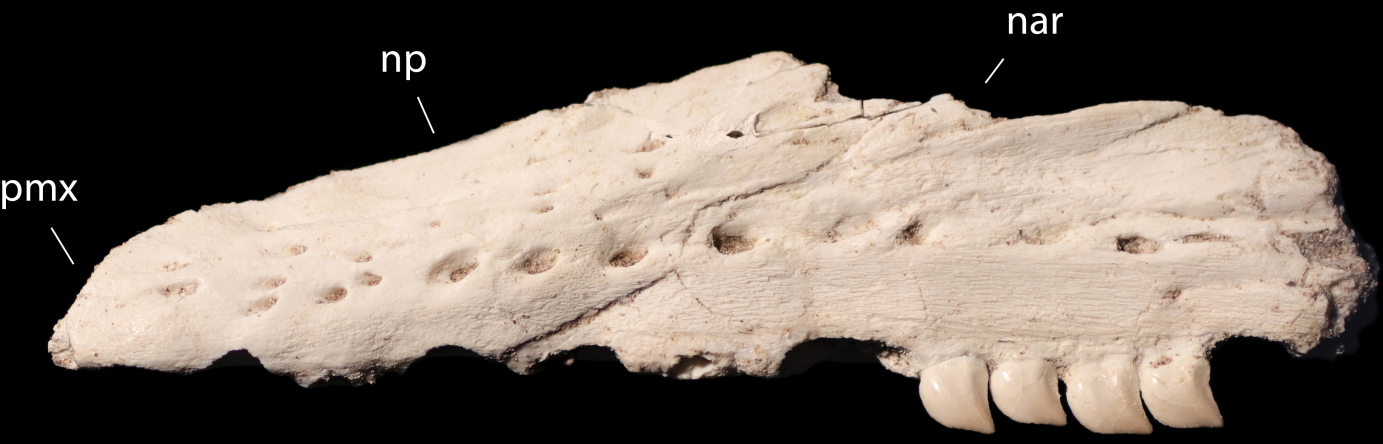

B

benek $-52+2$

C

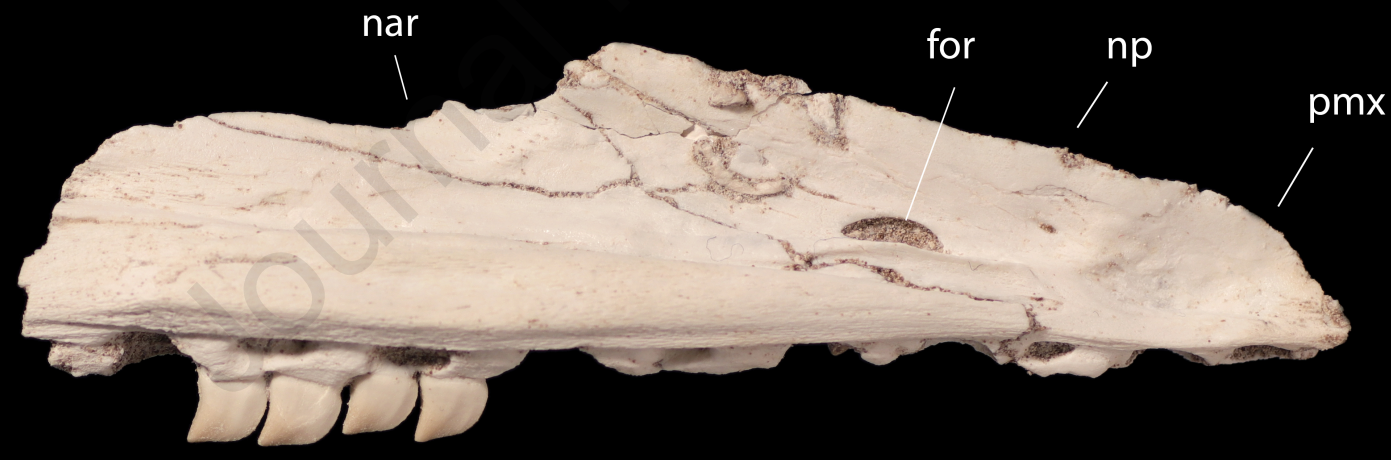

D

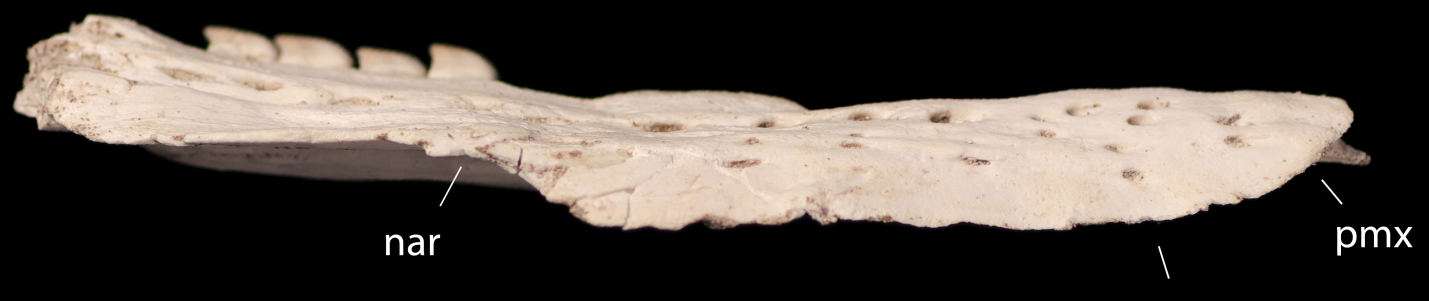

$50 \mathrm{~mm}$ 

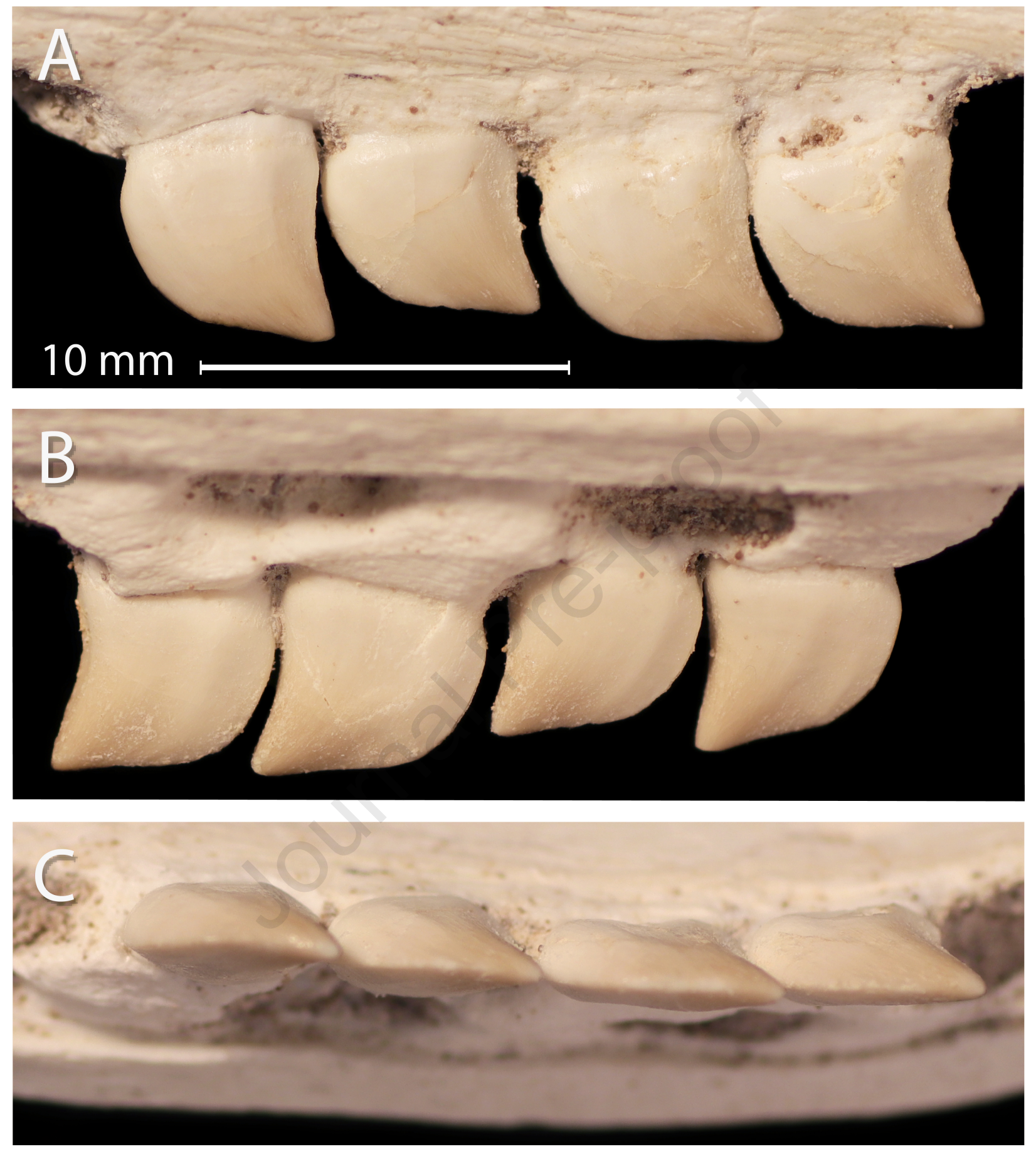


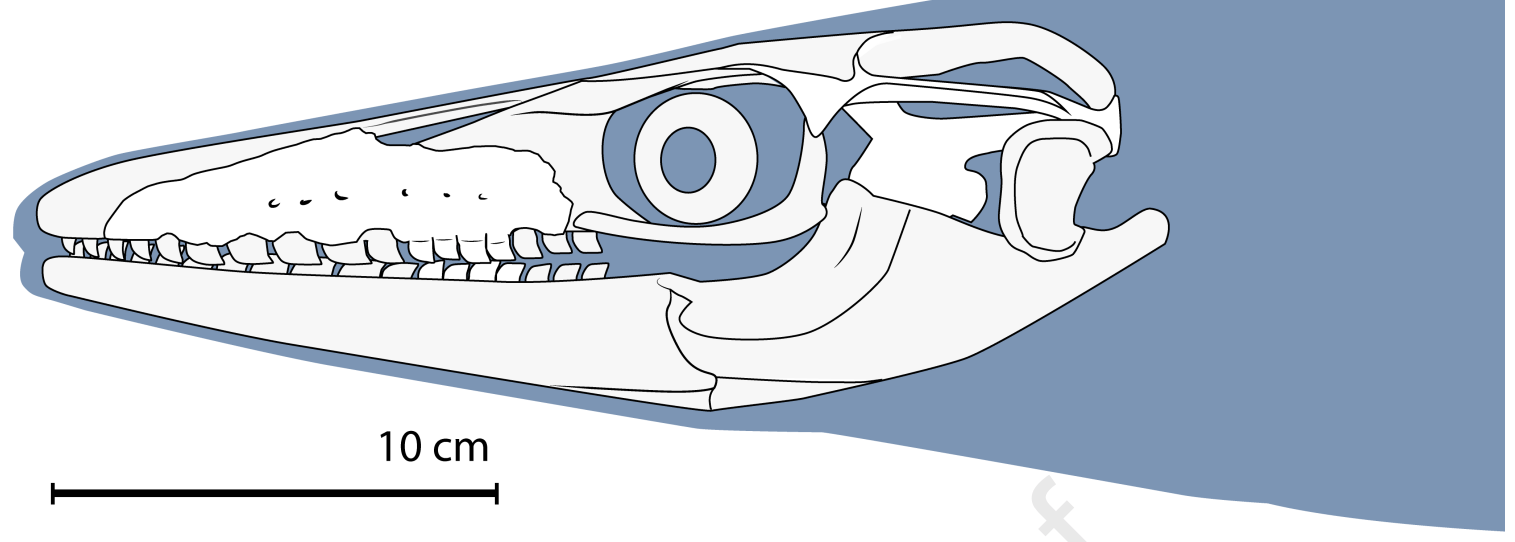




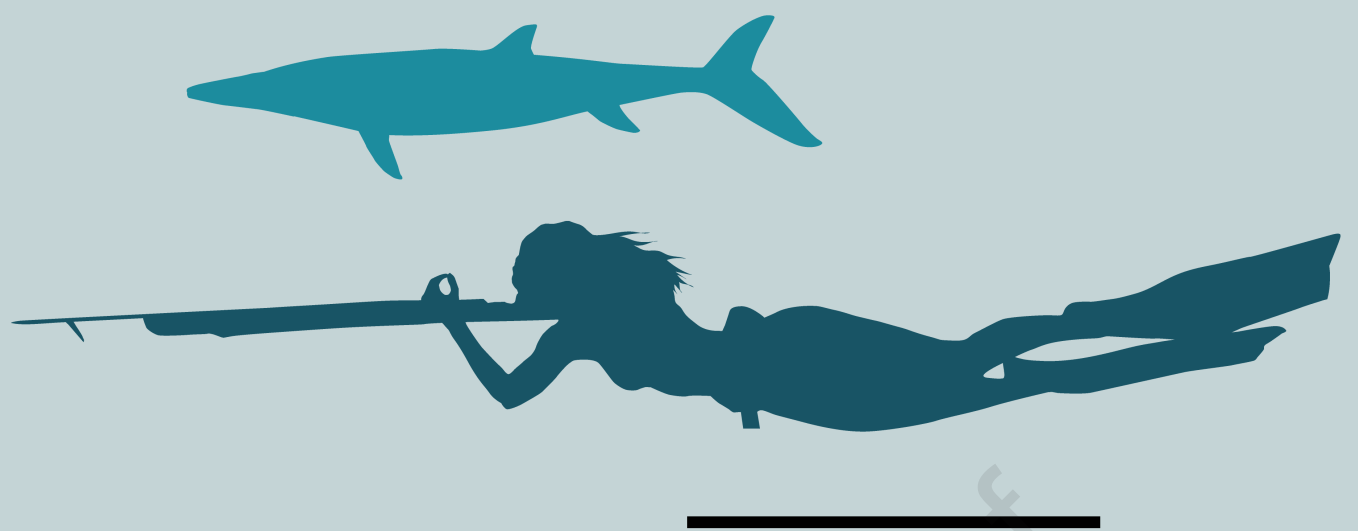




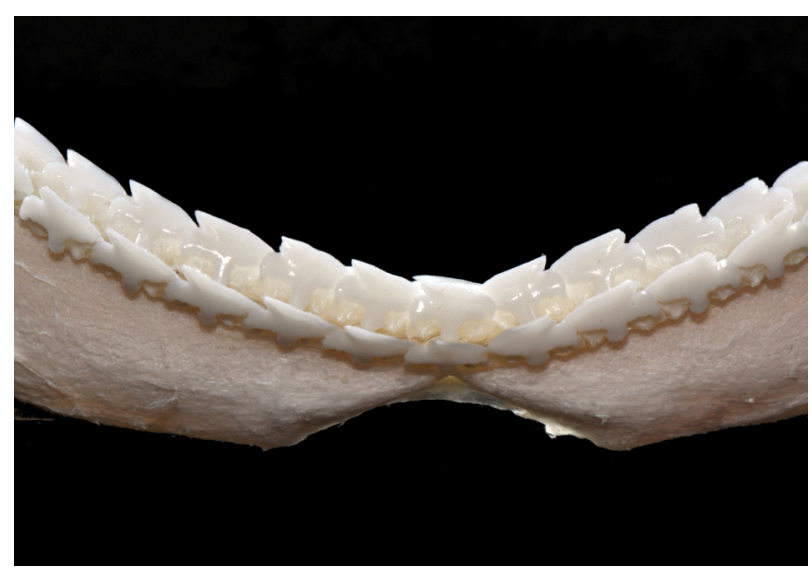




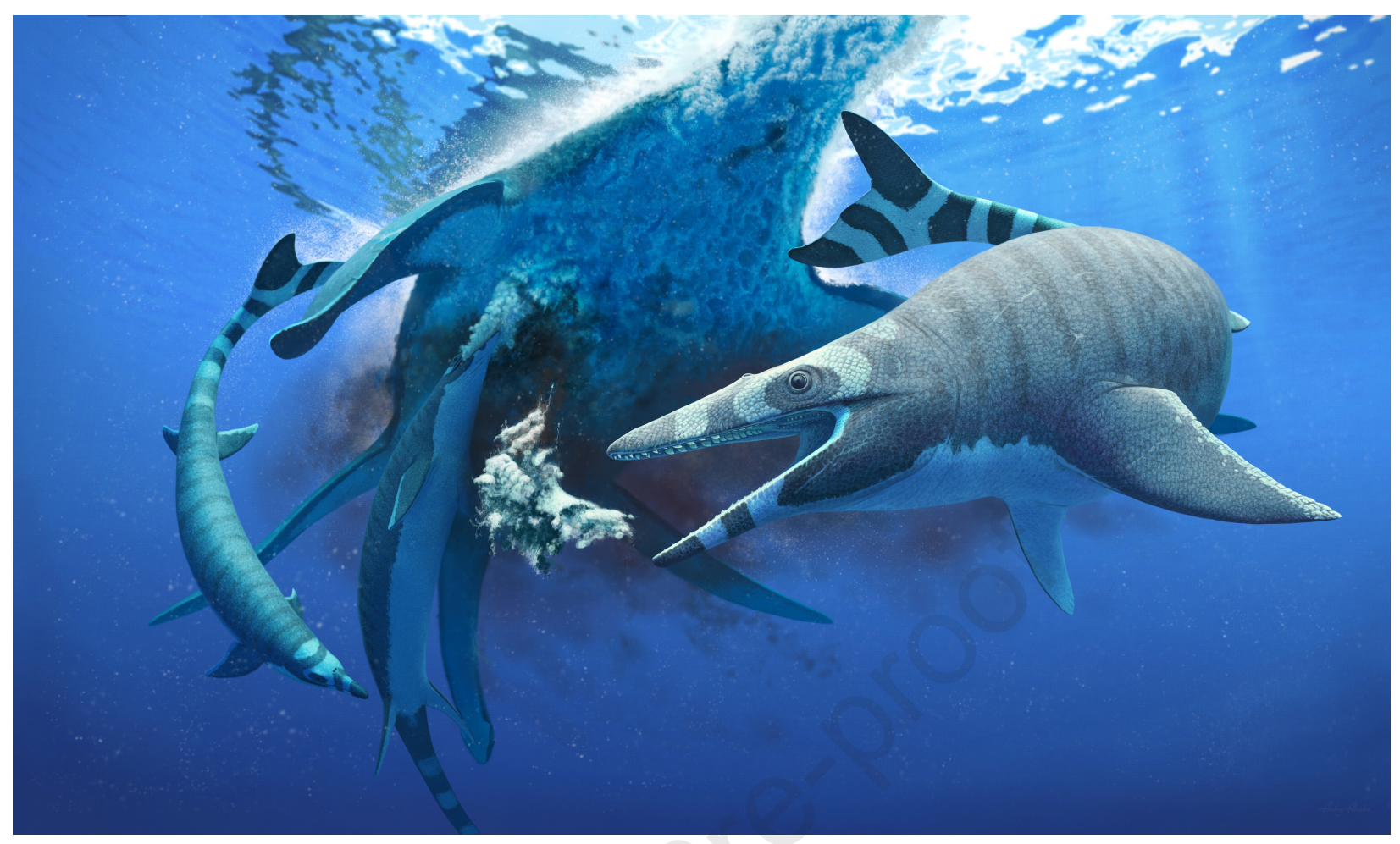




\section{Declaration of interests}

$\bigotimes$ The authors declare that they have no known competing financial interests or personal relationships that could have appeared to influence the work reported in this paper.

$\square$ The authors declare the following financial interests/personal relationships which may be considered as potential competing interests: 